\title{
The Mechanism of Arginine- and Insulin-Induced GH Release in Humans
}

\author{
KUNIHIKo HANEW \\ Hanew Endocrine Clinic, Sendai, Japan
}

Key words: Arginine, ITT, GH, GHRH-Antagonist, Normal Adults

(Endocrine Journal 47: S23-S27, 2000)

TO evaluate growth hormone (GH) secretory capacity, GH response to pharmacological stimuli, the spontaneous $24 \mathrm{hr}$ GH secretory profile, urinary $\mathrm{GH}$, plasma IGF-I and IGFBP-3 were employed. As a pharmacological stimuli L-dopa, clonidine, arginine, insulin and glucagon are used widely.

It is generally accepted that GH secretion is under the dual control of hypothalamic GHRH and somato-statin (SS). Previously we reported that Ldopa and clonidine stimulate GH secretion through the release of hypothalamic GHRH [1], but it is not clear whether arginine and insulin stimulate $\mathrm{GH}$ secretion via the release of GHRH or via the inhibition of SS.

It is reported that the second amino acid of GHRH is important for the receptor binding [2]. The amino acids of synthetic [N-Ac-Tyr $\left.{ }^{1}-\mathrm{D}-\mathrm{Ala}^{2}\right] \mathrm{GRF}(1-29)$ $\mathrm{NH}_{2}$ (GHRH-Ant) are different from human GHRH in the first and second positions, and it exerts a specific antagonistic action on human and rat GHRH receptors [1].

In this study $\mathrm{GH}$ releasing actions of arginine and insulin were examined by using GHRH-Ant in normal subjects whether these agents stimulate $\mathrm{GH}$ secretion via the hypothalmic GHRH release or not.

\section{Materials and Methods}

Seven normal adult males (21-30 yr) were examined in this study after obtaining approval from the ethical commitee and informed consent from every subject. In these subjects the following studies were performed: 1) single administration of arginine $(0.5 \mathrm{~g} / \mathrm{kg}$ iv from 0 to $30 \mathrm{~min})$ and insulin test (Insulin Tolerance Test, regular insulin, $0.05 \mathrm{U} / \mathrm{kg}$ iv at $0 \mathrm{~min}$ ) with or without combined administration of GHRH-Ant ( $800 \mu \mathrm{g}$ iv from 30 to $120 \mathrm{~min}), 2)$ sequential administration of GHRH(1-44) $\mathrm{NH}_{2}(100 \mu \mathrm{g}$ iv at 0 and $120 \mathrm{~min})$. 3) sequential administration of GHRH(1-44) $\mathrm{NH}_{2}(100 \mu \mathrm{g}$ iv at $0 \mathrm{~min})$ and arginine (iv from 120 to $150 \mathrm{~min}$ ) or insulin test (iv at $120 \mathrm{~min}$ ) with or without concomitant administration of GHRH-Ant ( $800 \mu \mathrm{g}$ iv from 90 to $240 \mathrm{~min}$ ).

Plasma samples were obtained $-30,0 \mathrm{~min}$ before and every $30 \mathrm{~min}$ until $120 \mathrm{~min}$ after the arginine test, and $-30,0 \mathrm{~min}$ and $15,30,45,60,90$ and $120 \mathrm{~min}$ after the insulin or GHRH test. Plasma GH was measured in duplicate with a high sensitivity IRMA kit (Daiichi, Tokyo), and the minimal detectable level was $0.006 \mu \mathrm{g} / \mathrm{L}$, and intra- and inter-assay coefficients of variation were $2.2 \%$ and $3.5 \%$, respectively. 

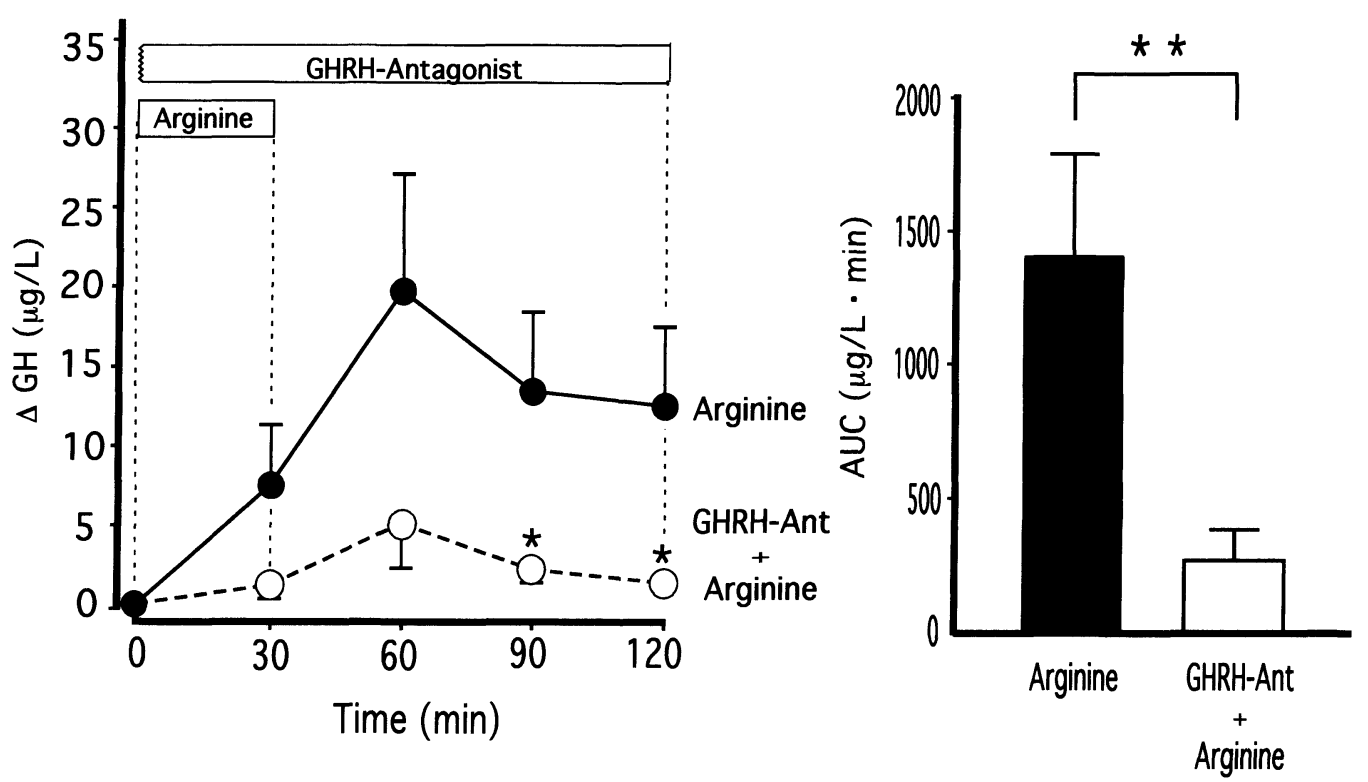

Fig. 1. Plasma GH responses to arginine with $(\bigcirc \ldots \bigcirc)$ or without $(\bullet-\bullet)$ combined administration of GHRH-Ant in 7 normal subjects. $\Delta \mathrm{GH}$, left panel; AUC, right panel. ${ }^{*} \mathrm{p}<0.05 ;{ }^{* *} \mathrm{P}<0.01$.

\section{Results}

Effect of GHRH-Ant on arginine- or insulin-induced $G H$ release

Plasma GH response to arginine was clearly inhibited by the concomitant administration of GHRH-
Ant $(\Delta \mathrm{GH}$ : arginine vs GHRH-Ant + arginine, $90 \mathrm{~min}, 13.4 \pm 4.8$ vs $2.2 \pm 0.7, \mathrm{P}<0.05 ; 120 \mathrm{~min}$, $12.5 \pm 4.9$ vs $1.3 \pm 0.6 \mu \mathrm{g} / \mathrm{L}, \quad \mathrm{P}<0.05$, Fig. 1). Similarly, plasma GH response to insulin was significantly inhibited by GHRH-Ant $(\Delta \mathrm{GH}$ : insulin vs GHRH-Ant + Insulin, $120 \mathrm{~min}, 10.9 \pm 5.7$ vs $1.3 \pm 0.8 \mu \mathrm{g} / \mathrm{L}, \mathrm{P}<0.01$, Fig. 2). The area under the response curve (AUC) calculated by trapezoidal
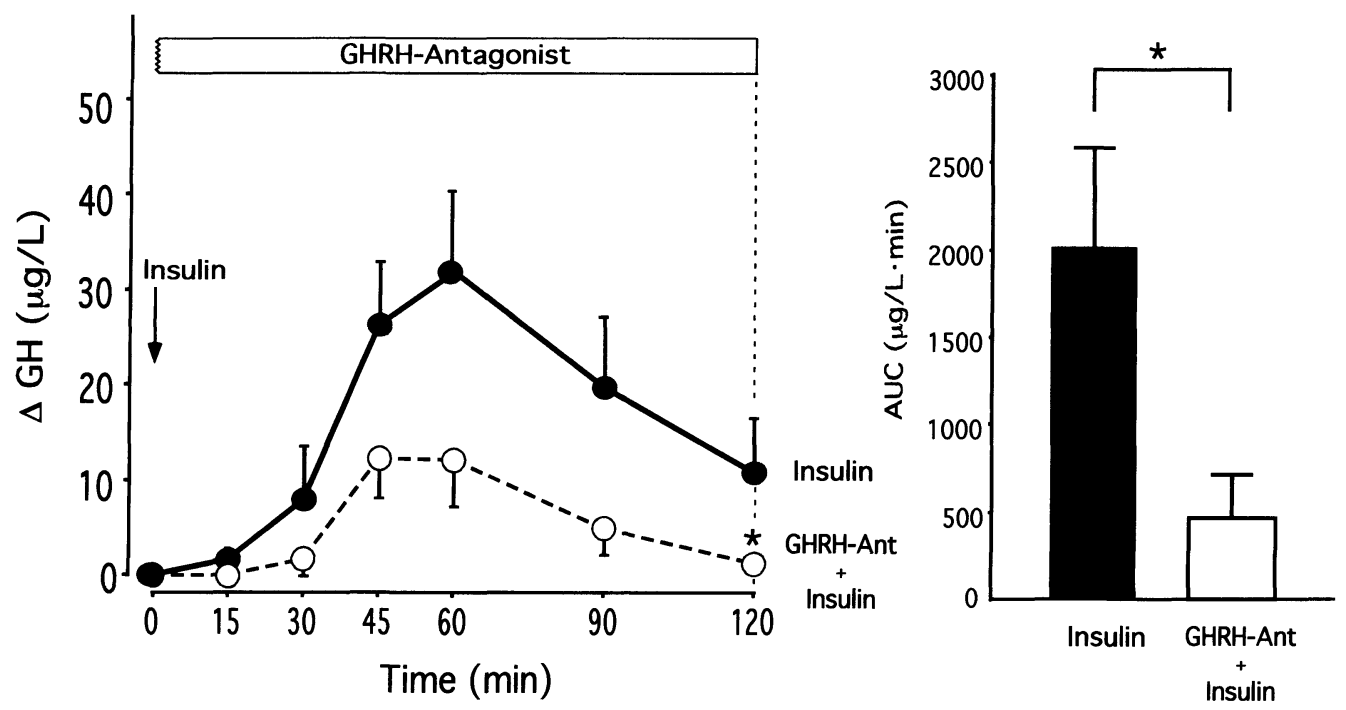

Fig. 2. Plasma GH responses to ITT with $\left(\mathrm{O}_{--} \bigcirc\right)$ or without $(\bullet-\bullet)$ combined administration of GHRH-Ant in 7 normal subjects. $\Delta \mathrm{GH}$, left panel; AUC, right panel. ${ }^{*} \mathrm{p}<0.05$. 



Fig. 3. Plasma GH responses to the sequential administration of GHRH and arginine with $(\bigcirc---\bigcirc)$ or without $(\bullet-\bullet)$ concomitant administration of GHRH-Ant. $\Delta \mathrm{GH}$, left panel; AUC, right panel. ${ }^{* *} \mathrm{P}<0.01$.

integration method was also significantly smaller in simultaneous administration of GHRH-Ant (arginine vs GHRH-Ant + arginine: $1404.7 \pm 381.3$ vs $271.5 \pm$ $114.7 \mu \mathrm{g} / \mathrm{L} \times \min , \mathrm{P}<0.01$, Fig. 1) (insulin vs GHRHAnt + insulin, $2012.7 \pm 566.5$ vs $467.6 \pm 242.5 \mu \mathrm{g} / \mathrm{L} \times$ $\min , \mathbf{P}<0.05$, Fig. 2).

Plasma GH response completely disappeared when GHRH was administered again 120 min after the first GHRH administration (data not shown). In contrast, distinct GH increase was observed when argi-
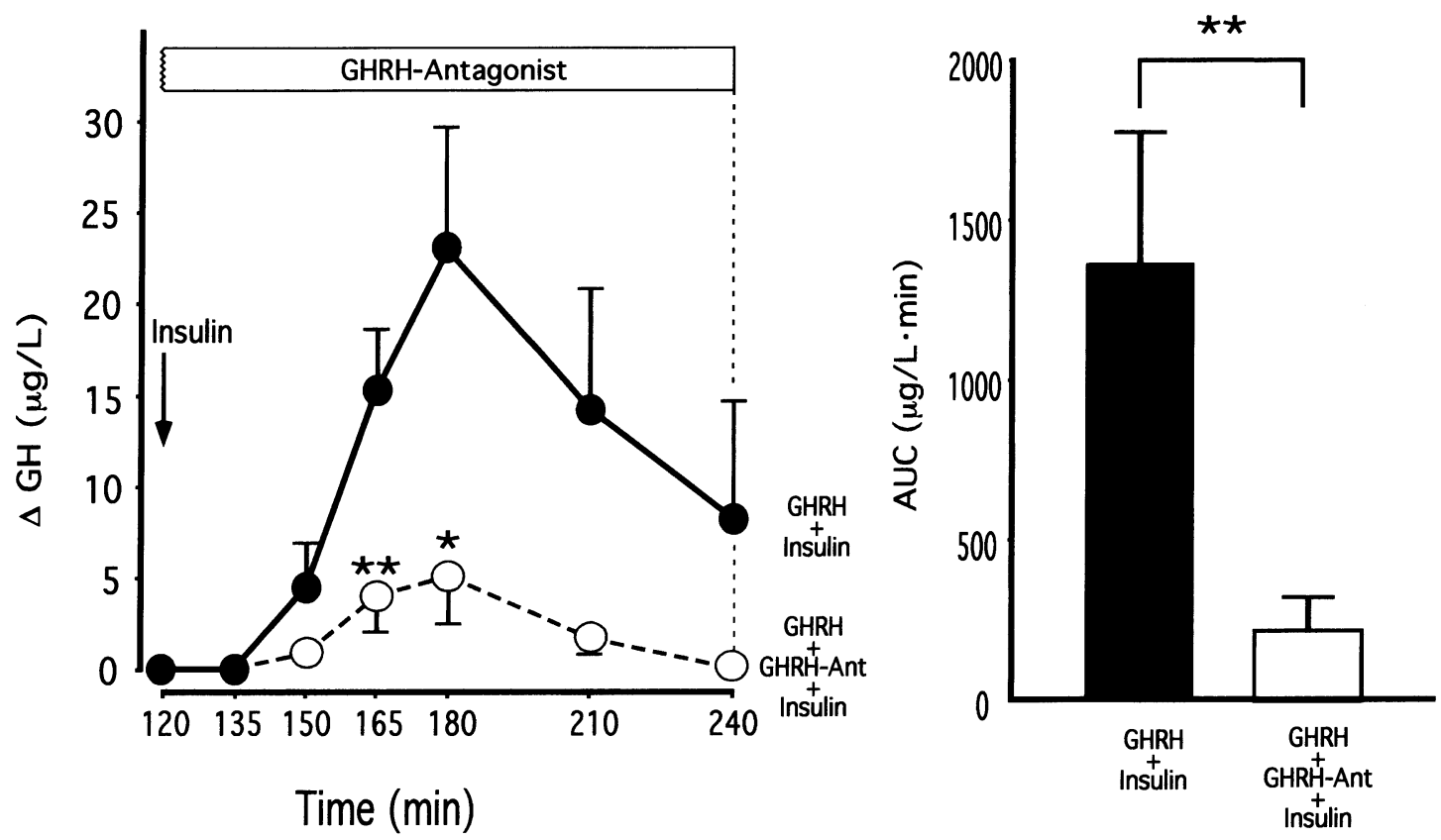

Fig. 4. Plasma GH responses to the sequential administration of GHRH and insulin with $(\bigcirc---\bigcirc)$ or without $(\bullet-\bullet)$ concomitant administration of GHRH-Ant. $\triangle \mathrm{GH}$, left panel; AUC, right panel. ${ }^{*} \mathrm{p}<0.05 ;{ }^{* *} \mathrm{P}<0.01$. 
nine or insulin was administered $120 \mathrm{~min}$ after GHRH injection. The preceding administration of GHRH-Ant evidently suppressed the above arginineinduced GH response $(\mathrm{GHRH}+$ arginine vs GHRH + GHRH-Ant + arginine: $\Delta \mathrm{GH}, 180 \mathrm{~min}$, $33.3 \pm 13.9$ vs $0.7 \pm 0.4, \mathrm{P}<0.01 ; 210 \mathrm{~min}, 24.7 \pm 12.9$ vs $1.2 \pm 1.2, \quad \mathrm{P}<0.01 ; \mathrm{AUC}, 2325.6 \pm 932.6$ vs $68.1 \pm 48.4 \mu \mathrm{g} / \mathrm{L} \times \min , \mathrm{P}<0.01$, Fig. 3) and insulininduced $\mathrm{GH}$ response $(\mathrm{GHRH}+$ insulin vs GHRH + GHRH-Ant + insulin: $\Delta$ GH, $165 \mathrm{~min}$, $15.3 \pm 3.3$ vs $4.0 \pm 1.9, \mathrm{P}<0.01 ; 180 \mathrm{~min}, 23.1 \pm 6.5$ vs $5.1 \pm 2.6, \quad \mathrm{P}<0.05 ; \quad \mathrm{AUC}, 1365.0 \pm 410.3$ vs $220.9 \pm 105.5 \mu \mathrm{g} / \mathrm{L} \times \min , \mathrm{P}<0.05$, Fig. 4).

\section{Discussion}

In this study, GH response to a single administration of arginine and insulin was significantly inhibited by the preceding administration of GHRH-Ant. The similar results were previouly reported by Jaffe $e t$ al. [3]. Further, GHRH-Ant significantly inhibited the GH secretion brought about sequential administration of these agents after GHRH injection. Previously we reported that L-dopa and clonidine seem to stimulate GH secretion in man through the release of hypothalamic GHRH since GHRH-Ant distinctly inhibited $\mathrm{GH}$ release induced by these secretagogues [1].

As was observed in this study, clear GH response occurred when arginine or insulin was sequentially administerd $120 \mathrm{~min}$ after GHRH administration, but $\mathrm{GH}$ response disappeared completely when GHRH was repeatedly administered $120 \mathrm{~min}$ after the first GHRH administration [4]. From these ob- servations and the fact that the GHRH dose used is pharmacological, it is theoretically difficult for arginine and insulin sequentially administered after GHRH to cause GH secretion via the hypothalamic GHRH release. Rather it seems that arginine and insulin inhibit hypothalamic SS release resulting in $\mathrm{GH}$ release.

GHRH promotes GH secretion by stimulating the adenylate-cyclase-cAMP system through Gs (stimulatory GTP-binding) protein, and SS decreases GH secretion by inhibiting the above system through Gi (inhibitory GTP-binding) protein [5].

The reason why GHRH-Ant inhibited the arginineand insulin-induced GH release is not clear, but it seems possible that some activation of the Gs protein-adenylate cyclase-cAMP system is required for $\mathrm{GH}$ release which is induced by the cancellation of somatostatinergic inhibition.

Recently the presence of a $G$ protein coupled phosphatidylinositol (PI)-protein kinase C (PKC) pathway was verified in humans, and GHRP-6 stimulates GH secretion through this system $[6,7]$. GH releasing activity of GHRP-6 is blunted in hypothalamic lesions which probably have GHRH deficiency [8]. This might imply that the presence of endogenous hypothalamic GHRH is required for the GHRP-6 activity. Together with this observation, the possibility that arginine and insulin stimulate $\mathrm{GH}$ release through the PI-PKC system should be taken into consideration.

In conclusion, while arginine and insulin stimulate GH secretion through a mechanism other than GHRH (e.g. inhibition of Gi protein or stimulation of the PKC system), endogenous hypothalamic GHRH is required for such stimulation.

\section{References}

1. Hanew K, Tanaka A, Utsumi A, Sugawara A, Abe K (1996) The inhibitory effects of growth hormonereleasing hormone (GHRH)-antagonist on GHRH, L-dopa, and clonidine-induced GH secretion in normal subjects. J Clinical Endocrinol Metab 81: 19521955.

2. Robberecht P, Coy DH, Waelbroeck M, Heiman ML, De Neef P, Camus JC, et al. (1985) Structural requirements for the activation of rat anterior pituitary adenylate cyclase by growth-hormone-releasing factor (GRF): discovery of (N-Ac-Tyr1, D-Arg2)-
GRF(1-29) $\mathrm{NH}_{2}$ as a GRF antagonist on membranes. Endocrinology 117: 1759-1764.

3. Jaffe CA, Friberg RD, Barkan AL (1996) Endogenous growth hormone $(\mathrm{GH})$-releasing hormone is required for GH responses to pharmacological stimuli. J Clin Invest 97: 934-940.

4. Shibasaki T, Hotta M, Masuda A, Imaki T, Obara N, Demura H, Ling N, Shizume K (1985) Plasma GH responses to GHRH and insulin-induced hypoglycemia in man. J Clin Endocrinol Metab 60: 1265-1267.

5. Hanew K, Tanaka A, Utsumi A (1998) Plasma GH 
responses to GHRH, arginine, L-dopa, pyridostigmine (PD), sequential administrations of GHRH and combined administration of PD and GHRH in Turner's syndrome. J Endocrinol Invest 21: 72-77.

6. Hanew K, Utsumi A, Tanaka A, Ikeda H, Yokogoshi Y (1998) Secretory mechanisms of growth hormone (GH)-releasing peptide, GH-releasing hormone-, and thyrotropin-releasing hormone-induced $\mathrm{GH}$ release in patients with acromegaly. J Clin Endocrinol Metab 83: 3578-3583.

7. Howard AD, Feighner SD, Cully DF, Arena JP,
Liberator PA, Rosenblum CI, et al. (1996) A receptor in pituitary and hypothalamus that functions in growth hormone release. Science 273: 974-977.

8. Popovic V, Damjanovic S, Micic D, Djurovic M, Diguez C, Casanueva FF (1995) Blocked growth hormone-releasing peptide (GHRP-6)-induced GH secretion and absence of the synergic action of GHRP-6 plus GH-releasing hormone in patients with hypothalamopituitary disconnection: evidence that GHRP-6 main action is exerted at the hypothalamic level. J Clin Endocrinol Metab 80: 3180-3184. 